\title{
Interactions between children, teenagers and botos (Inia araguaiaensis and Inia geoffrensis) in markets and fairs of Eastern Amazon
}

Angélica Lúcia Figueiredo Rodrigues, Gabriel Melo-Santos, lara Ramos-Santos, Ana Marta Andrade, Danilo Leal Arcoverde, Leonardo Sena, Maria Luisa da Silva

\begin{tabular}{|l|l|}
\hline Date of deposit & 09052019 \\
\hline Document version & Author's accepted manuscript \\
\hline Access rights & $\begin{array}{l}\text { C) 2019, Elsevier Ltd. All rights reserved. This work is made } \\
\text { available online in accordance with the publisher's policies. This is } \\
\text { the author created, accepted version manuscript following peer } \\
\text { review and may differ slightly from the final published version. }\end{array}$ \\
\hline $\begin{array}{l}\text { Citation for } \\
\text { published version }\end{array}$ & $\begin{array}{l}\text { Figueiredo Rodrigues, A.L., Melos-Santos, G., and Ramos-Santos, } \\
\text { I. (2019). Interactions between children, teenagers and botos } \\
\text { (Inia araguaiaensis and Inia geoffrensis) in markets and fairs of } \\
\text { Eastern Amazon. Ocean and Coastal Management, 172: pp137- } \\
145 .\end{array}$ \\
\hline $\begin{array}{l}\text { Link to published } \\
\text { version }\end{array}$ & \begin{tabular}{l} 
https://doi.org/j.ocecoaman.2019.02.005 \\
\hline
\end{tabular}
\end{tabular}

Full metadata for this item is available in St Andrews Research

Repository at: https://research-repository.st-andrews.ac.uk/

\section{St Andrews Research Repository}




\begin{abstract}
In this study we present the first record of interactions (ludic behavior, swimming and induced feeding) involving river dolphins known as botos (Inia sp.) and children/adolescents (from eight to 17 years old) at markets and fairs at the river front of two localities of Pará State, Brazil. We registered the reports of the participants using semi-structured interviews while they were working at the markets or when they were in the water to interact with river dolphins. We registered dolphins and human behavior using the ad libitum method. Most of the children interacting with botos were boys - we observed only two girls swimming with the dolphins. All the fish species offered to river dolphins are commercial. Tourists were often involved in interactions in the Santarém region, but not as frequently in the city of Mocajuba. Nevertheless, in both places human populations were aware of the interactions of children/adolescents with botos. The interviewees did not show fear of botos, as is common in other localities of Pará State. Although some of them attributed mystical powers to those animals. The children demonstrated to know about river dolphins behavior and morphology, as well as the occurrence of other species of aquatic mammals in the surrounding areas. Despite the diversity of aquatic mammals in those areas, we noticed that the knowledge of children regarded mainly botos and tucuxis (another river dolphin species), probably because these are the most conspicuous aquatic mammal species in the region. Furthermore, according to the reports of the interviewees these interactions between dolphins and humans have been going on for a long time in both areas, more than 30 years. The presence of newborn calves along our field observations indicate that this behavior may be passed down through generations of botos. In short, our results expand the knowledge regarding interactions between humans and Inia sp. in the Amazon. Moreover, it is essential to intensify the systematic research effort in order to evaluate effects of direct interaction activities on river dolphins and humans alike. In addition, educational measures in Eastern Amazon may promote realistic and efficient plans for the conservation of this species. Keywords: interactions, river dolphin, Amazon.
\end{abstract}




\section{Introduction}

The evolutionary history of humankind was founded on experiences with other species considering both biological and cultural aspects of these interactions. The explanations for such relationships established between humans and other animal species may be found in the biophilia hypothesis by Wilson (1984), which states the existence of an innate emotional bond between human beings and other life forms (Manfredo, 2008). Also, biophilia is the fundamental interdisciplinary field to investigate those interactions (Kahn Jr, 1997). According to Descola (1998), there is a variation in the sympathy and attitudes towards animals according to cultural traditions.

In this context, cetaceans have caught human attention for a long time, and some cultures, as in Greek mythology, those animals are seen as deities (Pantidou, 2014). Some authors point out that the sentiments and beliefs of humans regarding cetaceans are sufficient for considering the welfare of those species important (Barstow, 1991; Scheffer, 1991). The curiosity of men about cetaceans led to the confinement of various species in captivity. There are even some reports of an orca (Orcinus orca) in an enclosure made of nets while being attacked by soldiers armed with spears in Ancient Rome, and records of harbor porpoises (Phocaena phocaena) put into tanks of a privet collection in France during the 1400's (Collet \& Duguy, 1987). Furthermore, in recent years the frequency of direct interactions between humans and cetaceans has been increasing considerably due the larger amount of fisheries and tourism activities as dolphin and whale watching, and swimming with these animals (Lusseau, 2003; Lusseau \& Bejder, 2007; Reeves et al., 2003; Samuels et al., 2000).

Considering this increasing amount of interaction records between humans and cetaceans, our study focuses on interactions between humans and botos (Inia sp., Blainville, 1817), which are the largest of river dolphins and occur throughout the Amazon, Tocantins, Guamá and Orinoco river basins (Best \& da Silva, 1989; Da Silva et al., 2008; Hrbek et al., 2014; Santos et al. 2012, 2014). The behavior of these dolphins towards humans varies from shy to curious and even though some local communities and tourists consider the species charismatic, the relationship between botos and humans are not always harmonious. In the case of fisheries, the damage dolphins inflict to the nets cause losses and negative reaction by fishermen (Iriarte \& Marmontel, 2011; 2013). In the Amazon, interactions between dolphins 
and men usually occur in fisheries (Iriarte \& Marmontel, 2011; 2013) and social-cultural contexts in the case of legends and the commerce of byproducts of botos (Alves et al., 2010; Alves e Rosa, 2008), as well as in situations that attract tourism (Romagnoli, 2009; Alves et al., 2011; Alves et al., 2011).

According to Alves and colleagues (2012), botos (Inia geoffrensis) demonstrate a tolerant behavior towards activities involving humans and therefore tend to get closer often and to interact more with people. On the other hand, Aliaga-Rossel and his colleagues (2006) report that areas with high human activity may disrupt the grouping behavior of Inia boliviensis. In Central Amazon, interactions between botos (Inia geoffrensis) and tourists became popular in riverside communities of Amazonas State, and have been catching increasing attention of local and international media, attracting thousands of Brazilians and foreign tourists interested in feeding and swimming with these animals (Romagnoli et al., 2011; Alves et al., 2012).

Several studies describe the risks of interactions in which tourists swim with cetaceans (Constantine, 2001; Samuels \& Bejder 2004; Romagnoli et al., 2011). Moreover, other studies also demonstrated that unplanned tourism increases the levels of stress hormones in disturbed animals and may induce physiological changes and alterations in the blood biochemistry (UNEP, 2006). In addition, Alves and colleagues (2012) reported that when populations of botos are conditioned with food these dolphins might become aggressive towards each other and humans. Other risks to the animals include changes in behavioral patterns, health, and the dependence on induced feeding, in addition to the harm by tourists during the interactions (Orams et al., 1996; Orams, 2002; Alves et al., 2011).

In Eastern Amazon, more specifically in Pará State, Brazil, the influence of legends and myths related to river dolphins may lead children and teenagers to avoid such species, harmonious interactions are rare and hitherto not reported for this region (Rodrigues et al., 2012). Therefore, in this study we describe the interactions between children/adolescents and botos in markets/fairs in the towns of Mocajuba (lower Tocantins River) and Santarém (lower Tapajós River), in Pará State, Brazil, focusing on the context that those interactions occur and the most frequent behaviors observed in the process. 


\section{Methods}

\subsection{Study area}

We conducted our research in markets/fairs of two localities in Eastern Amazon, both located in Pará State, northern Brazil (Figure 1). One of these places is the town of Mocajuba $\left(2^{\circ} 35^{\prime} 31^{\prime \prime} \mathrm{S}, 49^{\circ} 28^{\prime} 60^{\prime \prime} \mathrm{W}\right)$ in the lower reaches of the Tocantins River. The other market/fair is located in the city of Santarém $\left(02^{\circ} 25^{\prime} 30^{\prime}\right.$ 'S e 5442'50”W) in the lower Tapajós River at the confluence with the Amazon River. Both the Tocantins and Tapajós are clearwater rivers with intermediate fertility (Junk et al. 2011). The lifestyle of human populations working or depending on the markets we studied share some common Amazonian characteristics as the consumption and commerce of products originated from the forests and rivers, such as fruits, fish and herbs. Even though the city of Santarém has a larger population and is more urbanized than Mocajuba, the market located on the margins of the Tapajós River still retains traits that connect city, countryside and nature (Lefebvre, 2001, p. 68).

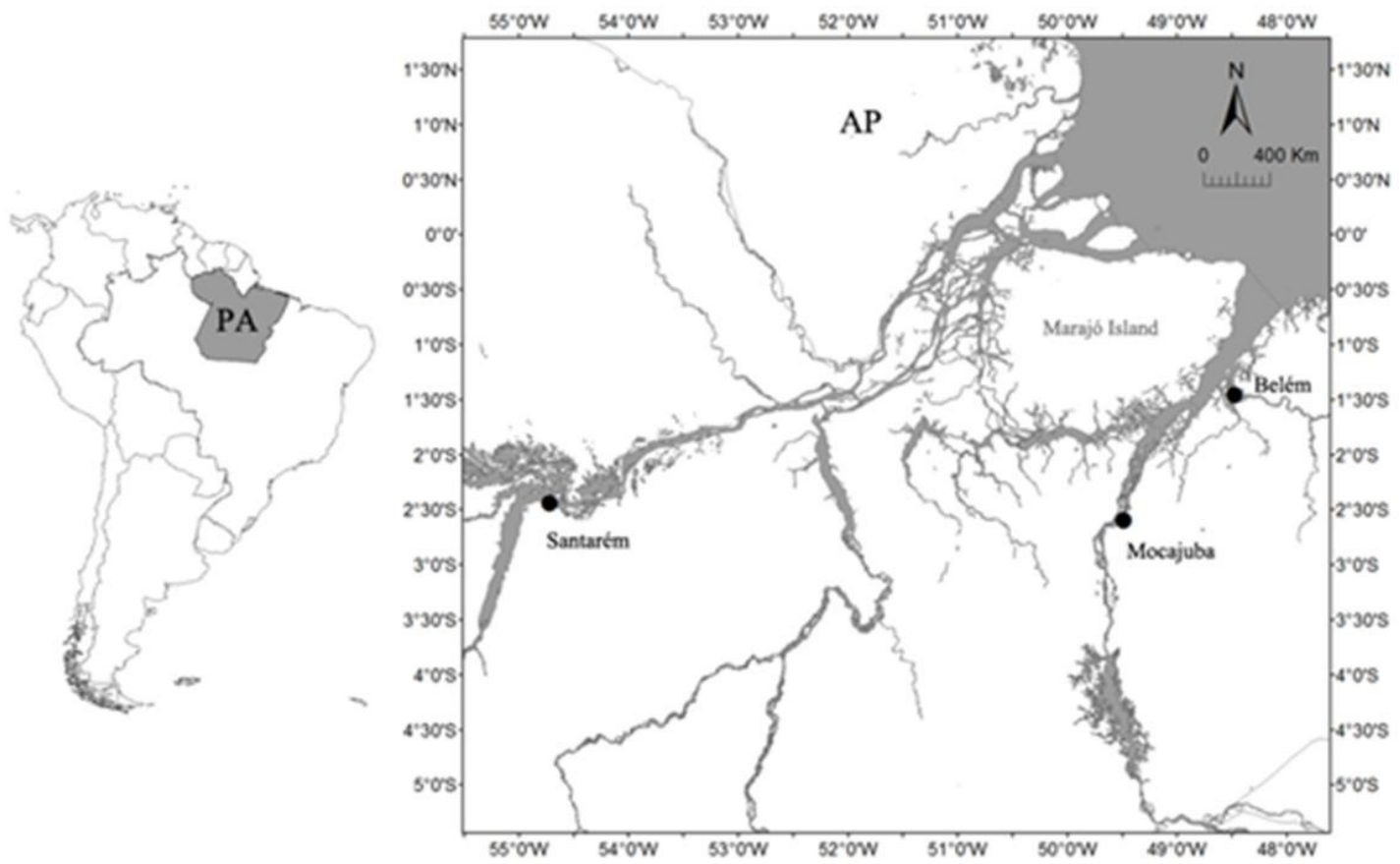

Figure 1. Location of the study areas showing Mocajuba (lower Tocantins River) and Santarém (lower Tapajós River).

\subsection{Data collection}

In order to contemplate the children's knowledge on river dolphins and their behaviors, we opted to collect their reports while in the market and during the interactions 
with the animals - before or after getting out of the water. To obtain the children's reports, we used opened or non-structured interviews, following Viertler (2002), that allows for a free and natural approach to the determined theme. Our questions focused on the experiences that children had with cetaceans, imbued with the stories told in the fair. Later, the answers were organized in categories according to the Bardin analysis (1977). To answer the main research objectives, the collected data was analyzed through the categorical analysis, which according to Bardin (2011) consists of the dismemberment of repertoires in categories according to the content of the reports obtained during interviews. We opted for this analysis due to its efficiency on studies regarding values, opinions, attitudes and beliefs through qualitative data. The Bardin content analysis is a technique of the communication sciences that analyzes what was said in interviews or observed by the researcher. The data is classified into themes or categories that help in a better comprehension of the interviewees content. Through the years the content analysis was used in a variety of data sources, as newspapers, politicians speeches, letters, advertisement, official reports, interviews, videos, films, photographs, magazines, autobiographical stories, among others (Silva and Fossá, 2015).

For the behavioral observations during interactions we used the ad libitum (Altman, 1974) observation method. Additionally, we took notes along with photographic and video footage to enhance the registration of information. According to Martin \& Bateson (2007), this is the most suitable method in situations with preliminary observations or rare records, which are considered relevant events.

Our observations took place in the morning, the period of more intense activity in markets and fairs of the Amazon region. Also, it was when the interviewees would be interacting with the dolphins, as they would be in school on the afternoon. We collected the information in Santarém during May 2013 (2 field days, 10 hours of effort), and in Mocajuba from October to December 2013 and March 2014 (13 days, 65 hours of effort). First, we contacted some people in the markets to obtain accurate information on the human-dolphin interactions, and then we used the places indicated by those contacts as platforms to observe the interactions between children and dolphins.

For each child interacting with botos, we took information on, if consented, name, age, and if they went to school, as parameters to draw a profile of the people interacting with botos. Then we took their addresses to ask their parents' permission for their participation in the research. The information and images we collected during the interviews and observations 
were authorized to be used by the parents of the interviewees by signing a written informed consent form (WICF).

\section{Results}

The dolphins participating of the interaction are from the species Inia geoffrensis for the Tapajós River and Inia araguaiaensis in the Tocantins River. During interactions botos continually rotate positions among themselves, so that all the individuals will get fish from people, nevertheless this does not mean that they are cooperating or competing with each other for the food.

During our research, we verified that in both suited areas that most of the people feeding/interacting with botos are young people from eight to 17 years old, students of public schools, part of low-income families and work in the markets/fairs on cleaning, selling snacks, or in fish commerce, because they need to contribute for their families' income. In Mocajuba we observed 12 children and teenagers interacting with dolphins, 10 boys and two girls. In Santarém we observed three children throwing fish to the dolphins.

In Santarem the fish that children offered to the dolphins are from the species: Pseudoplatystoma spp. ("surubim”, catfish), Hypophthalmus spp. ("mapará", catfish) and Piaractus brachypomus ("pirapitinga"), while in Mocajuba they offer: Hypophthalmus spp., Pellona castelnaeana ("sarda”, Amazon pellona), Hemiodus spp. (“jatuarana”). All offered species are commercial and sold in the studied markets/fairs. In Mocajuba, besides the fish, people also throw leftovers of red meat and chicken in the river, that eventually may be consumed or nibbled by river dolphins.

Santarém Market (Tapajós River)

In May 2013, we recorded the interactions between botos, Inia geoffrensis (locally known as "boto-rosa") and three children/teenagers in the lower reaches of the Tapajós River, more specifically in the municipal market. There one of the boys sold fish so the tourists could see him throwing them, tied to a string, in the water to attract the river dolphins pulling the tied fish up and down in order to make dolphins jump out of the water. In addition, we also observed that another two boys (between 15-17 years old) also throwing fish in the water, but 
without charging tourists for it, only doing it for fun, characterizing a ludic behavior of children towards botos.

We observed that botos gather to feed on the market leftovers as well. Therefore, people from the community saw in this scenario an opportunity to enhance their income or a game (Figure 2), one of our interviewees reported that the money from feeding botos can be used to buy toys and school supplies, items usually removed from the family budget to ensure basic needs such as food. During our observations, different dolphins came to the market each day, but we were unable to confirm whether some of the individuals revisited the market. Botos would come closer to the market as fish were thrown into the water whereupon they would remove the fish from the line (Figure 2).

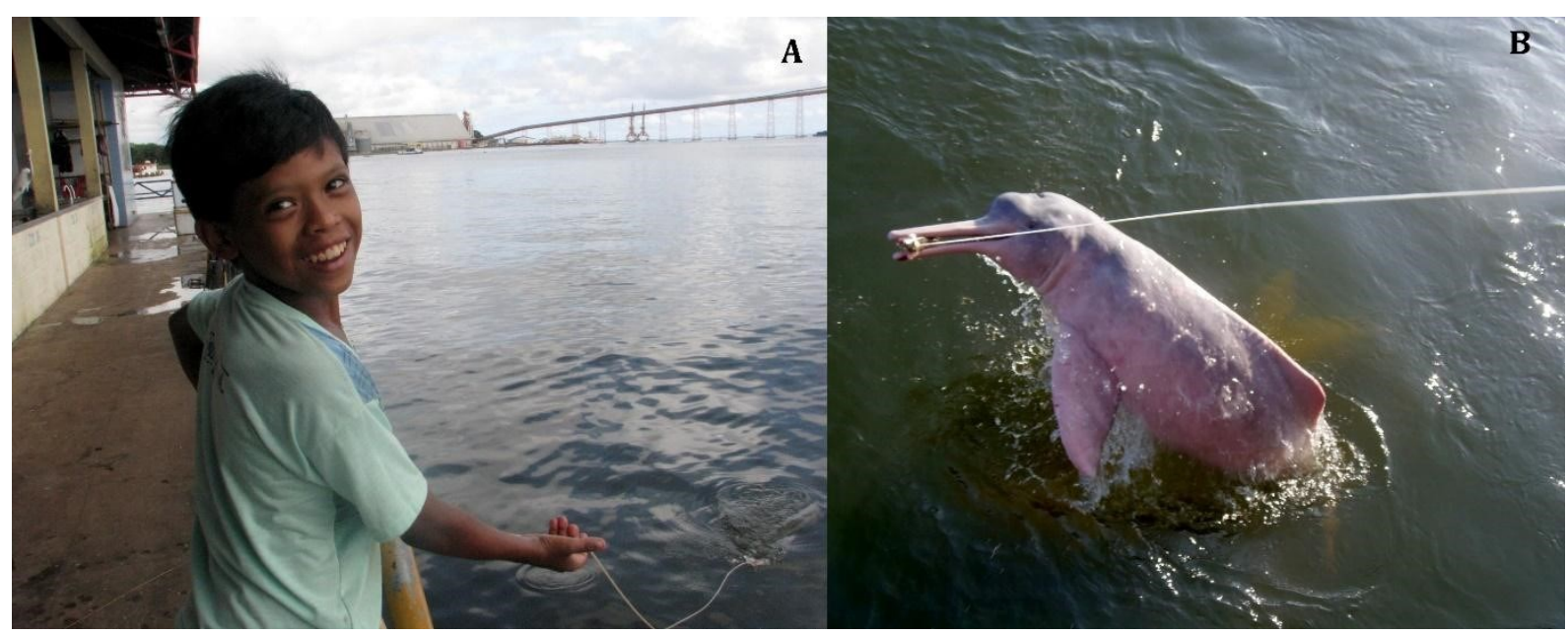

Figure 2. Interactions between boto (Inia geoffrensis) and children at the market of Santarém, Lower Tapajós River, Pará State, Brazil. Photos by: A. Angélica Rodrigues B. Gabriel MeloSantos.

We did not observe any direct interaction (feeding botos or swimming with them) between tourist and dolphins. We observed that the induced feeding arose the interest of tourists that would buy fish for the children to throw for botos. We did not find any sort of regulation regarding the interactions.

Mocajuba Market (Tocantins River)

In the lower Tocantins River, the children interact directly with botos swimming, caressing and feeding them with fish discarded by the marketers, or with fish that eventual tourists 
bought for them in order to watch dolphins being fed. This attitude towards the dolphins is likely to have been passed down through generations, according to some reports from workers in the market and other local people, human-dolphin interactions have been happening there for at least 30 years. These reports and the presence of newborn calves indicate that such behavior is being perpetuated in the populations of both species. Once more we face a playful behavior, regarding the children, in which the youngest learn from the oldest so that this playful behavior/interaction acquired local traits, typical of this region.

In the Mocajuba Market, we observed a group of about 13 botos, Inia araguaiaensis (locally known as "boto", "boto-rodelo", "boto-do-canal", "rudelo") interacting with children and teenagers from eight to 17 years old. From those, we were able to identify by natural marks four adult females, one female juvenile and a female calf, one adult male and a male calf. These individuals revisit the market often, and at least five of them do it on a daily basis. During this interactions there were two most conspicuous behaviors: 1) the induced feeding of dolphins, with children hitting the water surface with fish in order to attract and feed botos (Figure 3); 2) ludic/playful interactions when children would swim with, stroke and pull the fins (flukes and flippers of botos), climb on the dolphins dorsum, and hold the botos rostrum so they will not be able to open their mouths (Figure 4). The kids would mainly use fish to attract the dolphins. Even tough behaviors of children towards the dolphins may seem tough we did not observe any aggressive reactions from botos. Despite of that botos kept interacting with children even after fish was no longer provided, what led us to define this as a playful behavior. The interactions occurred when children were in their time-off of activities of the market or school, characterizing these interactions as recreational from the children's point of view as well. Transients at the market stopped and observed the human-dolphin interactions, this happened at least twice during our research.

In addition to direct interaction with children we also observed botos playing with human waste, as plastic bags and bottles, as well as food scraps as banana skins or pieces of meat, the latter might also be occasionally consumed (Figure 5). We also observed a dolphin playing with an Amazon puffer (Colomesus asellus), the boto held the fish in its mouth and shook it until it was puffed and then released it. Botos frequently touched one another during our observations, we even observed two animals swimming alongside each other with one holding the flipper of the other on its mouth. Another observation of object-carrying was a male holding a small pebble on the tip of the rostrum. Observations of dolphins swimming upside 
down were also common. Other frequently observed behavior was that when botos are given a large piece of fish another individual might chase the first and also grab the fish on the mouth, then both dolphins swam together until the fish was torn apart (Figure 6).

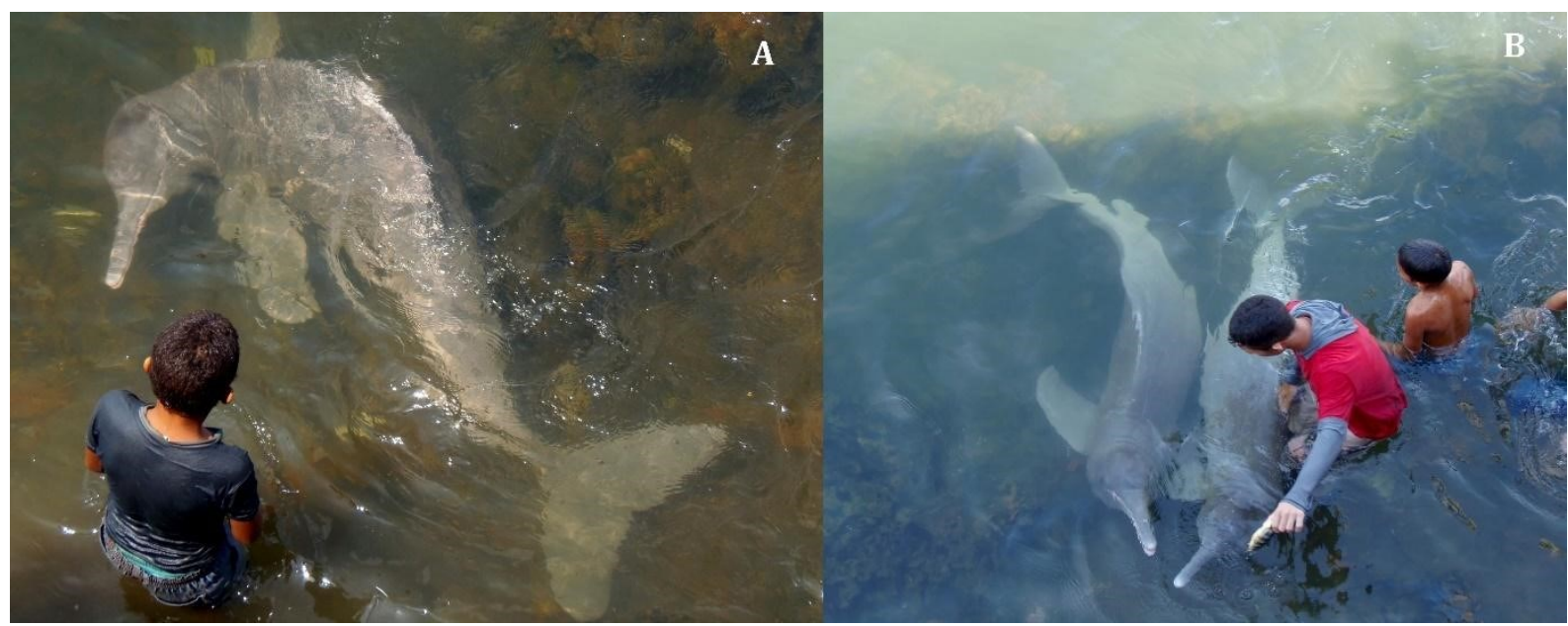

Figure 3. Araguaia botos (Inia araguaiaensis) interacting with children in front of the market of Mocajuba, Lower Tocantins River, Pará State, Brazil. Photos and B by Gabriel MeloSantos. 


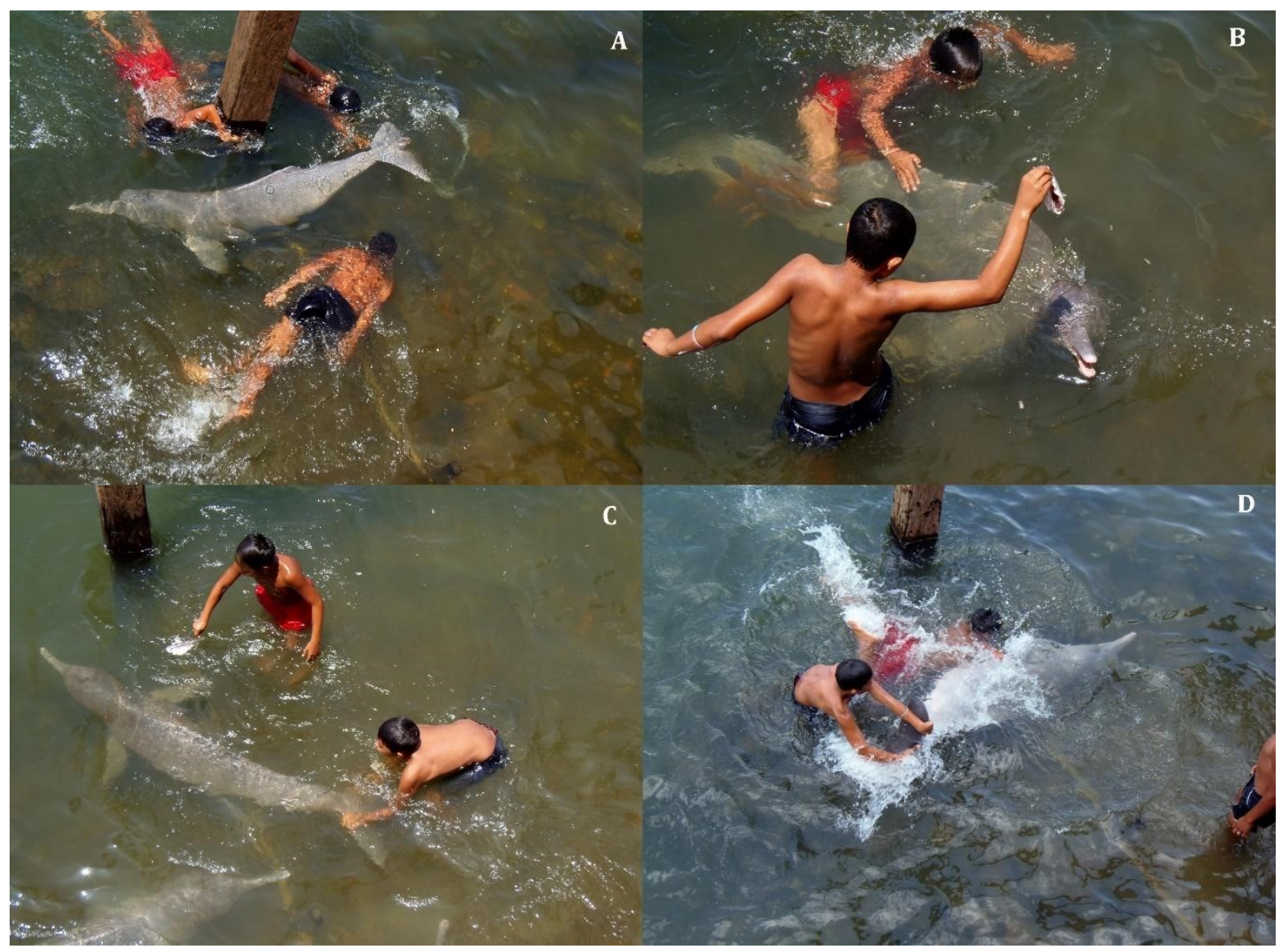

Figure 4. Direct interactions between Araguaia botos (Inia araguaiaensis) and children, the latter climb on the dolphin's dorsum and pull their flukes and flippers. Photos by Gabriel Melo-Santos. 


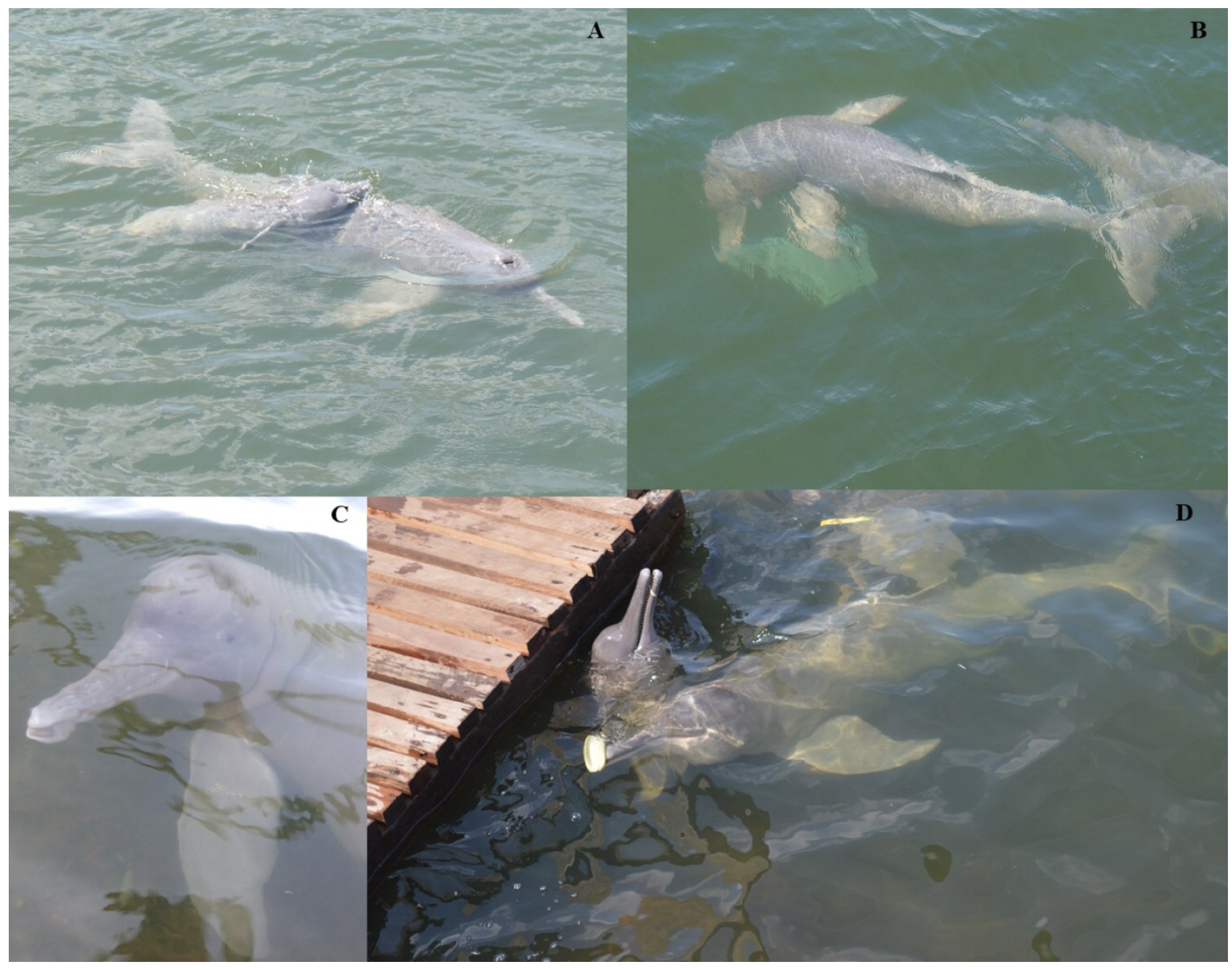

Figure 5. Observations of behaviors of botos Inia araguaiaensis at the surroundings of the Mocajuba Market. A - physical contact between mother and calf, B - boto playing with a plastic bag, $\mathrm{C}$ - boto holding a pebble with its mouth, $\mathrm{D}$ - boto playing with a banana skin. All photos by Gabriel Melo-Santos. 


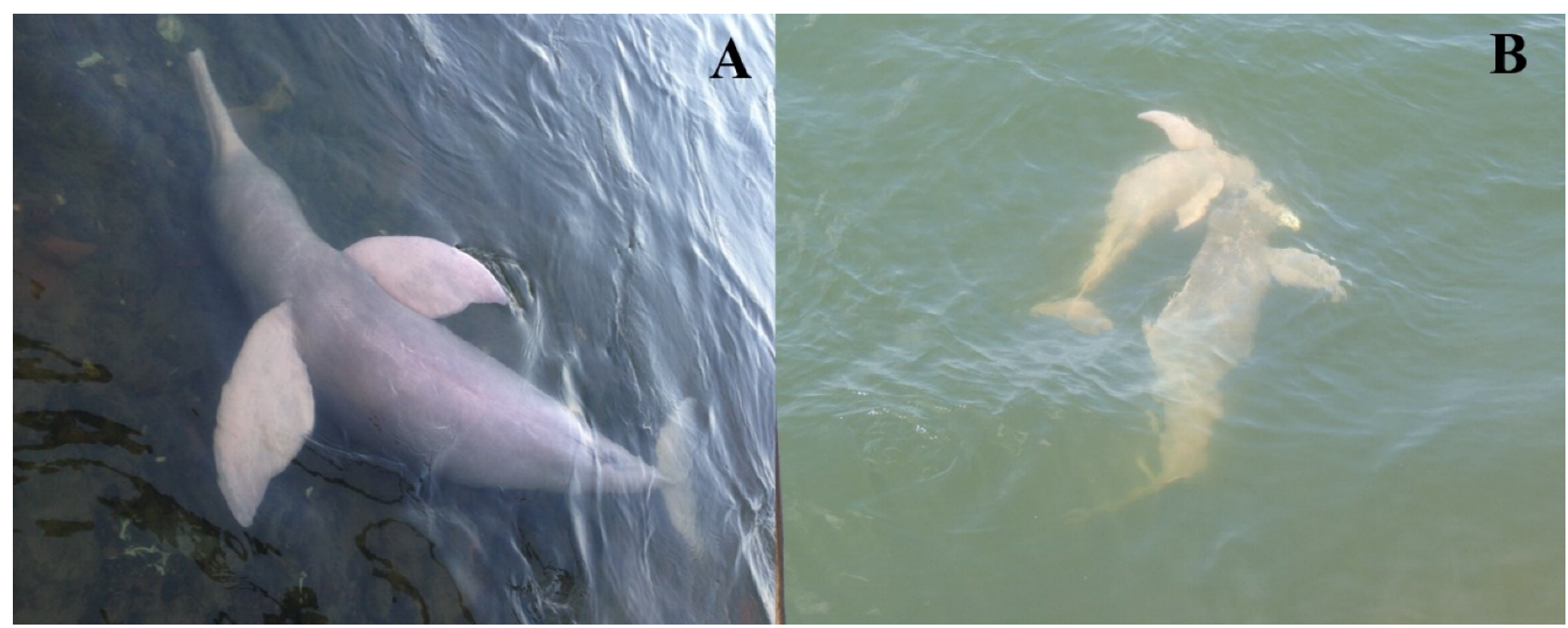

Figure 6. Observations of botos' behaviors at surroundings of Mocajuba market. A - female boto swimming upside down, B - botos grabbing a fish and swimming alongside each other. All photos by Gabriel Melo-Santos.

Due to the proximity with botos, children perceive traits of the animal's natural history accurately. For example, during our first day of observations the children pointed out that one of the river dolphins was pregnant, what we confirmed with our observations and by pictures, the genitalia as swollen and the body rounded, later one of the marketers reported that the calf was born around the $25^{\text {th }}$ of November in 2013. Our interviewees also state that they are able to recognize the animals individually. They report the larger dolphins as the cleverer individuals and that they take care of calves and juveniles. The children also give names to the botos and call the ones that come close to them as "frisky".

Given the situation, we looked for the children's parents to ask about their opinions and perceptions regarding the interaction with dolphins. We observed that some of the mothers feared for their kids when knowing that they have the habit to swim with and feed botos. Two of the interviewed mothers feared that botos would hunt their kids and take them to the "bottom of the river". Other parents allow the playing/interaction, but according to them, they try to accompany their kids to the market to avoid accidents during interactions.

The interviewees reported only one accident, according to them one of the boys got accidentally bitten while feeding a dolphin, statement later confirmed by the boy in question. Even though these interactions may seem as an activity involving more boys, this apparently was not an issue or a taboo, during our fieldwork two girls (from 10 to 12 years old) reported 
to swim with botos and we also observed one eight-year-old girl swimming with and feeding the dolphins. However, another interviewed girl revealed to be afraid to swim with botos and to be taken to the "river bottom", and that is why she would not dare to do so. That is our only record of a girl fearfully referring to human-dolphin interactions in that area.

We noticed constant plea on the reports from kids and workers at the market to maintain the botos in the condition of induced feeding. Because of occasional curious tourists that might visit the market to observe the event and buy fish to offer to the animals, as we observed along the study. During our fieldwork we only observed one tourist feeding botos, but it was evident that market workers increase their sales when there are people interested in feeding botos. Children do not profit from this activity, but participate only handing the fish to botos, if solicited by the tourist.

\subsection{Ethnozoological knowledge about Amazonian aquatic mammals}

In a general, the children have extensive knowledge and experiences with Amazonian aquatic mammals, regarding biological, morphological, behavioral and ecological aspects of those animals. The amount of information that they know might vary according to the species and locality. We summarized the answers of the children on their knowledge on Amazonian aquatic mammals on Table 1, the categories were created according to the Bardin analysis (1977). Most answers on aquatic mammals' biology referred to morphological and behavioral aspects. Regarding the diversity of aquatic mammals in the Amazon, we noticed that children's knowledge was mainly related to botos (Inia sp.) and tucuxis (Sotalia fluviatilis), the most conspicuous aquatic mammals in the region.

Table 1: Ethnozoological perceptions of children regarding botos in Mocajuba,

PA, as categorized by the Brdin analysis of content. Children's transcribed speeches are between quotes while author's comments about their perceptions are in bold 


\begin{tabular}{l|l}
$\begin{array}{c}\text { Behavior of botos: } \\
\text { referring to boto's } \\
\text { behavior repertoire } \\
\text { perceived by the } \\
\text { children }\end{array}$ & $\begin{array}{l}\text { "During interaction when botos blew loud" } \\
\text { produced by the dolphin's blowhole was loud. }\end{array}$ \\
& $\begin{array}{l}\text { "At first the botos are shy, but after they get used to someone, then } \\
\text { that is it, the animals come closer and closer." }\end{array}$ \\
$\begin{array}{l}\text { The interviewees report that at first, botos present a shy behavior } \\
\text { towards newcomers, but after fish provision, they tend to come } \\
\text { closer. This may also refer to the fact that younger calves usually } \\
\text { keep a distance from humans, but may be seen among the adults } \\
\text { often swimming under them. }\end{array}$
\end{tabular}

\section{Morphological} aspects:

Anatomical parts as perceived by the children, a structure might have several names
"The male is smaller, angrier, and female has rounder beak and is more docile, shows itself more, rolls around showing the belly."

Children state to be able to identify the sex of individuals even pointing out traits they believe to be sexual dimorphism. They also associate behavioral traits to specific individuals, sex or age class.

The children refer to the flippers as "flaps". They are also able to correlate dolphins' anatomical parts with human ones. For example, they equal the flippers to the human arm, they also identified the blowhole as the nose of the animal and described that this is the structure responsible for respiration.

The kids also report to recognize each dolphin by the shape and color of the rostrum and by spots on the animals' bellies.

They also say that two calves were born since they started interacting with botos. Moreover, they state to recognize pregnancy by a more rounded belly. 


\begin{tabular}{|c|c|}
\hline $\begin{array}{c}\text { Occurrences of } \\
\text { other species of } \\
\text { aquatic mammals: } \\
\text { During the interviews, } \\
\text { the children showed } \\
\text { to know other aquatic } \\
\text { mammals species } \\
\text { besides botos, as } \\
\text { manatees and otters }\end{array}$ & $\begin{array}{l}\text { "The tucuxi does not come close to the market". } \\
\text { "There are no manatees in Mocajuba, but there are around Cametá } \\
\text { (another town next Mocajuba)." } \\
\text { "It is just like boto, but its face is thinner and longer, it eats weeds" } \\
\text { (referring to manatee eating aquatic plants). } \\
\text { "I've heard about giant river otter but it does not occur in the } \\
\text { region". }\end{array}$ \\
\hline $\begin{array}{c}\text { Legends: } \\
\text { There are legends that } \\
\text { attribute mystical } \\
\text { powers to botos. } \\
\text { These legends might } \\
\text { incite fear and } \\
\text { negative feelings } \\
\text { towards river } \\
\text { dolphins. }\end{array}$ & $\begin{array}{l}\text { "Man is different from a woman. A Woman "de bode" (menstruating) } \\
\text { cannot get into the water because the boto will go after her." } \\
\text { "There is a man (Otavio). He dives here and crosses over to the other } \\
\text { side of the river, he swims along with botos, here is a boto, he walks } \\
\text { with the botos, when he comes out of the water he keeps flailing (the } \\
\text { boy who told the story stirred like a fish out of water while narrating). } \\
\text { He might be "pirara*", you should not mess with him. He is haunted, } \\
\text { one cannot mess with him. He is old, he is sick, his arm is crooked, } \\
\text { and he walks naked." } \\
\text { *Pirara is a local fish, but in the sentence is referred to mad/crazy } \\
\text { behavior. }\end{array}$ \\
\hline
\end{tabular}

\section{Discussion}

- Interactions between boto (Inia sp.) children at the market

In this study, we report the occurrence of interactions between botos and children that live in two localities of Pará. One of them is located in the lower Tocantins River region and the other one in the lower Tapajós River. At the Santarém market, the interactions occur basically in the induced feeding context, even though children may perceive it as ludic behavior. On another hand, at the Mocajuba market, interactions are direct and dolphins and children remain interacting even after fish provision stops, with constant touching caressing, and sometimes pulling by the children, and, surprisingly, no aggressive reaction by botos. 
While in Santarém the interaction may be economically skewed, as money earned on botos feeding may be used to complement family income, in Mocajuba they occur in a recreational context. Children get into the water with botos during their free time from the market work or school. Interactions such as these are unique records in the region. Orams (2002) and Alves and colleagues (2013) state that feeding river dolphins as a tourist attraction is controversial and presents serious negative implication, for both cetaceans and tourists. Although there are references to psychological, social and economic benefits associated to the interactions (Orams, 2002).

In Western Amazon induced feeding promotes frequent interactions and may induce hierarchical and/or aggressive behavior among boto groups (Alves et al., 2012; Romagnoli et al., 2011). Nevertheless, we have not recorded any expressive aggressive behavior among botos in our study, botos may occasionally bite each other on the neck. Additionally, the group observed in the Mocajuba Market is predominantly formed by females and calves, with only one adult male identified so far (Melo-Santos et al., 2018, in prep). In the study of Alves and colleagues groups are mostly composed by males. This might relate to more frequent observations of aggressive and hierarchical behavior in their set up when compared to ours. The reality of the Amazon is similar to places in Australia, where wild dolphins were conditioned to receive food from tourists without previous studies about the potential damage that these activities might cause for both aquatic mammals and humans (Orams 2002; Alves et al., 2013).

We did not detect any touristic regulation in Santarém and Mocajuba for this type of activity, not even studies showing interaction effects. Animals that are commonly close to human activities are more likely to be involved in collisions with boats, as reported by Zappes and colleagues (2013) for cetaceans of the Brazilian coast and Central Amazon. They are also more susceptible to harm by tourists after our study two of the botos from Mocajuba were harmed by people, one female had her melon cut with a nylon string or knife and an adult male had his rostrum tied to a nylon string, then tied to one of the poles of the market peer, this resulted in a deep cut. In Novo Airão region, Amazonas State, Alves and colleagues (2011) also report that there is no code of conduct for tourists during the interactions with botos, and the few rules established in the floating platforms for tourists are not respected.

Another potential harm for animals fed by humans is an increased risk of calf' mortality because females divert from the search for food and focus their attention on humans, 
as reported by Lipman (2015) for dolphins in Australia. This causes reduction of contact between mother and calf, thus affecting the welfare and survival of infants (Lipman, 2015). Nevertheless, we did not observe any divergency between mother and calves in both of our sites.

Regarding the risks of accidents for people, the interviewees reported a case of a boy who had his fingers bitten while was feeding one of the dolphins. Alves et al. (2011) reported accidents such as these for tourists artificially feeding river dolphins in Novo Airão region, state of Amazonas, Brazil. In addition, these authors emphasize that groups of male botos may cause these types of accidents while disputing over food.

In case the of Santarém, we emphasize an economic aspect of this activity, since it helps to complement the budget of low-income families, as every time fish are thrown to botos, the number of individuals around the market increases and so does the number of tourists paying to see river dolphins. Similarly, in the coastal region of Pará State, children help on smaller tasks of fisheries and, as they grow older, adults give them major responsibilities also contributing to the family income (Torres, 2004).

In the lower Tocantins region, children and teenagers interact directly with botos, swimming, caressing and feeding them. The continuation of interaction after food provision by children with continuous physical contact between humans and dolphins (children pull their flippers, stroke their dorsum and even hold tight and pull their rostrum), as well as the corporal and facial expressions of children (as laughter) characterize a ludic behavior (Yamamoto \& Carvalho, 2002). Playful behavior is present in several species of mammals, it refers to the physical, social, emotional and cognitive development of youngsters (Hansen et al., 2007). According to Spinka and colleagues (2001), the games serve as a motor and emotional training for situations involving responses in case of predation and other social interactions. We observed various social-playful behaviors observed for botos on the Mocajuba market, as carrying rocks, passing vegetation branches among individuals and playing with puffer-fish, all recorded concomitantly with the interactions with children (Santos et al., 2014). The Mocajuba market is not only a place where botos obtain food, but our observations show that animals use the area for social activities as well. Object-carrying plays an important role in boto's behavior as it is related to courtship behavior (Martin et al., 2008), thus the playful behavior with objects in the market are may serve as training and preparation for this social-sexual display (Spinka et al., 2001). 
This emotional and social development is also observed in the interaction between children and other animal groups. Experts including medical doctors, anthropologists and veterinarians have proved that in case of pets, the human-animal interactions can potentially improve the capacity, social skills and behavior that reinforce caring in children and adults (Savishinsky, 1983; Melson \& Fogel, 1989). Although research involving human-animal interaction has increased, the idea that the company of animals can contribute to the health of patients is not yet recognized by medicine (Serpell, 1996).

The behaviors analyzed in this study may have been inherited from previous generations as newborn calves have been observed along our field observations from 20132018 (personal observation) in addition older residents' of Mocajuba report that such interactions have been occurring for nearly 30 years. Moreira (2003) states that families that sustain from fisheries participate not only passing down values but also function as the core of teaching of professional knowledge.

Human-dolphin interactions concern the children's parents in Mocajuba due to potential danger related to the direct contact with botos and, because of legends associated to these animals in the Amazon. Some parents prefer to forbid their children to swim with botos, but usually, they try to go with them to the market to avoid accidents. The mythological aspect involving the Amazonian botos is evident in the speech of the interviewees of Mocajuba. Representing another area in the Amazonian region where the myth of the dolphins that transforms into man to seduce and get women pregnant is present in the folklore of riverside communities, as evidenced by Alves (2007), Ramos et al. (2011), Rodrigues (2012) and Paschoal et al. (2013).

The reports of legends in Mocajuba might be one of the reasons that human-boto interactions involve predominantly boys. Nevertheless we did observe girls swimming and playing with botos. Different from other regions in the Amazon where the relation girl-boto is a taboo, for example the Abaetetuba islands, located downstream from Mocajuba in the Tocantins River (Rodrigues et al., 2012).

\section{- Children's ethnozoological knowledge on Amazonian aquatic mammals}

Our interviewees seem to know about some biological characteristics of aquatic mammal groups and apparently recognize some individual botos associating the larger ones as caregivers of calves and juveniles, and those who come close to people are denominated 
“frisky". Tunnicliffe \& Reis (1999) report that descriptions of children between four and 14 years old tend to mention animal sizes, naming individual animals, and referring to their anatomical traits.

Romagnoli and colleagues (2011) affirm that interactions between botos and humans in the Amazon region are very peculiar. One of the reasons is the different behavior of botos compared to marine dolphins since the former are curious and naturally come closer to humans, with a flexible skeleton allowing them to reach shallow areas near riverbanks. The closer relationship between cetaceans and children enhance their perception regarding biological and natural history aspects of the animals. Torres (2004) claims that fishermen and other social groups in the Amazon region can perceive dynamic processes inherent to the ecosystems based on their collective experiences, what makes them capable to identify in detail aspects related to the biodiversity, such as different species of fish.

Interviewees demonstrated to have previous ethnozoological knowledge on morphological and behavioral aspects of botos. Regarding the diversity and occurrence of other aquatic mammal species in the region, we observed that their knowledge is mainly related to botos (Inia sp.) and tucuxis (Sotalia fluviatilis), probably because those are the most conspicuous species of aquatic mammals in the Amazon. Rodrigues \& Silva (2012) investigated the perceptions of riverside community students about river dolphins in two public schools. In both schools, most students classified botos as fish, they also demonstrate to know more than one species of river dolphin by differentiating coloration patterns.

Chen $\mathrm{Ku}$ and $\mathrm{Ku}(1998)$ studied the perceptions and classifications of animals within Aboriginal students in Hualien region (China) and concluded that, regardless of grade level, most children were unable to designate the most common attributes of animal species and their subclasses. First of all, children tend to verify individual characteristics of each animal species, or try to differentiate them by comparison with other animals to finally define categories for the animal species.

\section{Conclusion}

The present study is part of a research about interactions between children and teenagers in school-age with botos in their natural environment in Eastern Amazon. This scenario provided us the opportunity to understand their perceptions and knowledge on botos 
and other aquatic mammals of the Amazon. The information we presented here can subside the creation environmental education and outreach programs in schools and local communities, in order to promote the conservation of aquatic mammals.

At the Santarém market, we observed that the context of human-boto interactions is similar to that described for Amazonas State. Both are economically skewed, aiming mainly supplementary income. In Mocajuba, that relationship is different, much closer and playful there is no significant economical appeal.

Even though cultural aspects as the legend of the boto tends to make human-boto interactions a predominantly male activity it does not restrict the involvement of girls in these activities. We did observe two girls interacting with dolphins in Mocajuba.

Unlike other sites of human-boto interactions in the Amazon, the group of botos that visit the Mocajuba market is predominantly formed by females (some accompanied by calves), with only one adult male. According to reports of Mocajuba residents these interactions have been happening for at least 30 years. This information along with the constant observation of calves in the area suggest that such activities have been passing down generations.

Nevertheless, our study shows an increase in human-boto interactions in the Amazonian region, promoted by the media. Even though these activities may be profitable for human local communities, several authors have described how human-cetacean interactions can be harmful to the animals. The demand for studies to understand how such interactions may affect river dolphins biology, behavior and conservation, as well as human and dolphin health is urgent. This information is needed in order to foment sustainable practices so as to maintain the cultural customs of local communities and to guarantee animals welfare.

In the educational point of view, children and teenagers can improve their empiric knowledge about botos. Since they spend time observing the animals in their natural environment, despite potential risks during the process of interaction. Even though reported as harmful in other areas there are possible benefits from such interactions. The interest of children about of dolphins can be used to support the creation of conservation and outreach programs. These children should have key roles in those programs acting as peers and dispersers into their local communities, catching attention of family and friends for the conservation of river dolphins. 
It is necessary to systematically expand the research in Mocajuba and Santarém, as they represent a huge opportunity to study biology and behavior of botos and understand how these dolphins deal with anthropogenic pressure. Furthermore, scientists and local communities can interact in an educational approach and place the biological aspect as a guiding point for shaping conservation programs that better suit the local reality.

\section{Acknowledgments}

We would like to thank the families and children in the cities of Santarém and Mocajuba. We also thank the veterinarians Luiza Pereira and Jairo Moura for their support in the field research. The first author was granted by a scholarship of the Conselho Nacional de Desenvolvimento Científico e Tecnológico (CNPq).

\section{References}

ALIAGA-ROSSEL, E.; MCGUIRE, T.; HAMILTON, H. Distribution and encounter rates of the river dolphin (Inia geoffrensis boliviensis) in the central Bolivian Amazon. The Journal of Cetacean Research and Management. 8(1): 87-92. 2006.

ALTMANN, J. Observational study of behavior: sampling methods. Behaviour. 49: 227-267. 1974

ALVES, L.S.A. A constituição do discurso narrativo polifônico da criança: traços da mitopoética amazônica. Educação Infantil e Estudos da Infância na Amazônia. Editora UFPA, EDUFPA. Belém, Brasil. 2007.

ALVES, R.R.N; CAMPOS, B.A.T.P.; TOLEDO, G.A.C; MOURÃO, J.S.; BARBOZA, R.R.D.; SOUTO, W.M.S. Traditional uses and conservation of dolphins in Brazil. In: PEARCE, A. G.; CORREA L. M. (Org.) Dolphins: Anatomy, Behavior and Threats. Nova Science Publishers, p.2-15. 2010.

ALVES, L. C. P. D. S.; ANDRIOLO, A.; ORAMS, M. B.; AZEVEDO, A. D. F. The growth of 'botos feeding tourism', a new tourism industry based on the boto (Amazon river dolphin) Inia geoffrensis in the Amazonas State, Brazil. Sitientibus série Ciências Biológicas, 11 (1): 8-15. 201. 
AlveS, L. C. P. S.; ZAPPES, C. A.; ANDRIOLO, A. Conflicts between river dolphins (Cetacea: Odontoceti) and fisheries in the Central Amazon: a path toward tragedy? Zoologia (Curitiba). 29 (5): 420-429. 2012.

ALVES, R. R. N.; ROSA, I. L. Use of tucuxi dolphin Sotalia fluviatilis for medicinal and magic/religious purpose in North of Brazil. Human Ecology 36: 443-447. 2008.

ALVES, L. C. P.; SARTORI, M. A., ANDRIOLO A.; AZEVEDO de F. A. Alimentação artificial de botos-da-Amazônia (Inia geoffrensis, de Blainville 1817) como atração turística e sua dispersão pela Amazônia Brasileira. Revista Brasileira de Zoociências, $13(1,2,3): 8-15.2013$.

BARDIN L. Análise de conteúdo. Lisboa: Edições 70. 1977.

BARSTOW, R. Whales are uniquely special. In: Daves, n.; Dmith, A.M.; Whyte, S.R.; Williams, V. (Org.). Why Whales?. Whale and dolphin Conservation Society. Bath, Inglaterra. p. 4-7. 1991.

BEST, R. C.; DA SILVA, V. M. Biology, status and conservation of Inia geoffrensis in the Amazon and Orinoco river basins. Occasional paper SSC. 3: 23-33. 1989.

CHEN, S. H.; KU, C. H. Aboriginal children's alternative conceptions of animals and animal classification. Proceedings-National Science Council Republic of China part D. Mathematics Science and Technology Education. 8 (1): 55-67. 1998.

COLlET, A.; DUGUY, R. Les Dauphins: historiqueetbiologie. Science et Decouvertes, Le Rocher, Monaco. 123pp. 1987.

CONSTANTINE, R. Increased avoidance of swimmers by wild bottlenose dolphins (Tursiops truncatus) due to long_term exposure to swim_with_dolphin tourism. Marine Mammal Science.17(4): 689-702. 2001.

DA SILVA, V.; GOULDING, M.; BARTHEM, R. Golfinhos da Amazônia. $1^{\text {a }}$ Ed. Editora Instituto Nacional de Pesquisas da Amazônia - INPA. Manaus, Brasil. 43 pp. 2008.

DESCOLA, P. Estrutura ou sentimento: a relação com o animal na Amazônia. Mana. 4(1): 23-45. 1998.

FARIAS, J.G.; MELO-SANTOS, G.; RODRIGUES, A.L.F.; FARIAS, I. P.; HRBEK, T. Distribution of the Araguaian boto, Inia araguaiaensis (Cetartiodactyla: Iniidae), and the discovery of I. araguaiaensis/geoffrensis hybrids in the lower reaches of the Tocantins river. Checklist, in press. 
GONÇALVES, D. C. M.; GAMA, J. R. V.; OLIVEIRA, F. A.; OLIVEIRA JUNIOR, R. C.; ARAÚJO, G. C.; ALMEIDA, L. S. Aspectos Mercadológicos dos Produtos não Madeireiros na Economia de Santarém-Pará, Brasil. Floresta e Ambiente. 19(1): 9-16. 2012.

HANSEN J, MACARINI S.M. MARTINS G.D.F, WANDERLIND F.H, VIEIRA M.L. O brincar e suas implicações para o desenvolvimento infantil a partir da Psicologia Evolucionista. Rev Bras Crescimento Desenvolv Hum. 17(2):133-143. 2007.

HRBEK, T.; DA SILVA, V. M. F.; DUTRA, N.; GRAVENA, W.; MARTIN, A. R.; FARIAS, I. P. A new species of river dolphin from Brazil or: how little do we know our biodiversity. PloS one. 9(1): e83623. 2014.

IRIARTE, V.; MARMONTEL, M. Report of an encounter with a human intentionally entangled Amazon River dolphin (Inia geoffrensis) calf and its release in Tefé River, Amazonas State, Brazil. Uakari. 7(2): 29-33. 2011.

IRIARTE, V.; MARMONTEL, M. River Dolphin (Inia geoffrensis, Sotalia fluviatilis) Mortality Events Attributed to Artisanal Fisheries in the Western Brazilian Amazon. Aquatic Mammals. 39(2): 116-124. 2013.

KAHN JR, P. H. Developmental psychology and the biophilia hypothesis: Children's affiliation with nature. Developmental review. 17(1): 1-61. 1997.

JUNK, Wolfgang J. et al. A classification of major naturally-occurring Amazonian lowland wetlands. Wetlands, v. 31, n. 4, p. 623-640. 2011.

LEFEBVRE, Henry. O Direito à Cidade. Tradução de Rubens Eduardo Frias. 4. ed. São Paulo: CENTAURO. 2001.

LIPMAN, S. How the Wild Dolphin Feeding Industry Threatens This Species' Survival. Disponível em: http://www.onegreenplanet.org/animalsandnature/howthewilddolphin-feeding-industry-threatens-this-species-sunvival/ Acessado em: 07/02/2015.

LUSSEAU, D. Male and female bottlenose dolphins (Tursiops spp.) have different strategies to avoid interactions with tour boats in Doubtful Sound, New Zealand. Marine Ecology Progress Series. 257:267-274. 2003.

LUSSEAU, D.; BEJDER, L. The long-term consequences of short-term responses to disturbance experiences from whale watching impact assessment. International Journal of Comparative Psychology. 20 (2): 228-236. 2007.

MANFREDO, M. J. Who cares about wildlife? Social science concepts for exploring human-wildlife relationships and conservation issues. Springer. New York. USA. 228pp. 2008. 
MARTIN, P.; BATESON, P. Measuring Behaviour: An Introductory Guide, $3^{\mathrm{a}} \mathrm{ed}$. Cambridge University Press, Cambridge, Inglaterra. 222pp. 2007.

MELO-SANTOS G, RODRIGUES ALF, ARCOVERDE DL, RAMOS I, SENA L, KRAMER D, MARMONTEL M, DA SILVA ML, MENDES-OLIVEIRA AC. New records of river dolphins in Eastern Amazon. In prep.

MELSON, G. F.; FOGEL, A. Children's Ideas about Animal Young and their Care: A Reassessment of Gender Differences in the Development of Nurturance. Anthrozoos: A Multidisciplinary Journal of The Interactions of People \& Animals. 2(4): 265-273. 1989.

MOREIRA, E. S. Tradição em tempos de modernidade: reprodução social numa comunidade varzeira do rio Xingu/PA. Editora Universitária UFPA. Belém, Brasil. 2003.

ORAMS, Mark B.; HILL, Greg JE; BAGLIONI, Anthony J. "pushy” behavior in a wild dolphin feeding program at Tangalooma, Australia. Marine Mammal Science, v. 12, n. 1, p. 107-117. 1996.

ORAMS, M. B. Feeding wildlife as a tourism attraction: issues and impacts. Tourism Manage. 23(3): 281-293. 2002.

PANTIDOU, G. All about dolphins in secondary education. In: Samuels, J. B. (Org.). Dolphins: Ecology, behavior and conservation strategies. Nova Publications, New York, USA, p.83-128. 2014.

PASCHOAL, E. D. M.; MONTEIRO-FILHO, E. L. D. A.; MARMONTEL, M. Local knowledge of the Amazon river dolphin (Inia geoffrensis Blainville, 1817) in the Lake Amanã region, Amazonas. UAKARI. 9(1): 25-35. 2013.

RAMOS, R.G., MARTINS, B.M.L., \& RODRIGUES, A.L.F. Percepção estudantil nos Municípios de Abaetetuba e Maracanã (Vila de Algodoal), para conservação de pequenos cetáceos. In: Educação Ambiental: responsabilidade para a conservação da sociobiodiversidade. Seabra, G. \& Mendonça, I. (Ogs.). João Pessoa: Editora Universitária da UFPB. 2011.

REEVES, R. R., SMITH, B. D., CRESPO, E. A. and Notarbartolo di Sciara, G. (Org.). Dolphins, whales and porpoises: 2002-2010 conservation action plan for the world's cetaceans. IUCN/SSC Cetacean Specialist Group. IUCN, Gland, Switzerland \& Cambridge, UK. 139pp. 2003.

RODRIGUES, A. L. F.; DA SILVA, M. L. Botos: realidade e fantasia na concepção de estudantes ribeirinhos do estado do Pará, Brasil. Natural Resources. 2(1): 29-43. 2012. 
ROMAGNOLI, F. C. Interpretação ambiental e envolvimento comunitário: ecoturismo como ferramenta para a conservação do boto-vermelho, Iniageoffrensis. Boletim do Museu Paraense Emílio Goeldi Ciências Humanas. 4(3): 569-569. 2009.

ROMAGNOLI, F. C.; DA SILVA, V. M. F.; NELSON, S. P.; SHEPARD-JR, G. H. Proposta para o turismo de interação com botos-vermelhos: como trilhar o caminho do ecoturismo? 4(3):463-480. 2011.

SAMUELS, A.; BEJDER, L.; HEINRICH, S. A Review of the Literature Pertaining to Swimming with Wild Dolphins. Marine Mammal Commission. Bethesda, Maryland. 58pp. 2000.

SAMUELS, A.; BEJDER, L. Chronic interaction between humans and free-ranging bottlenose dolphins near Panama City Beach, Florida. Journal of Cetacean Research and Management. 6(1): 69-77. 2004.

SANTOS, G. M. A.; QUARESMA, A. C.; BARATA, R. R.; MARTINS, B. M. L.; SICILIANO, S.; SILVA-JR., J. S.; EMIN-LIMA, R. Etho-ecological study of the Amazon River dolphin, Inia geoffrensis (Cetacea: Iniidae), and the dolphins of the genus Sotalia (Cetacea: Delphinidae) in Guamá River, Amazonia. Marine Biodiversity Records. 5 (23): 1-5. 2012.

SANTOS, G.M.A.; RODRIGUES, A.L.F.; ARCOVERDE, D.L.; RAMOS, I.; SENA,L.; SILVA, DA M.L. Unusual Records of the Behavior of boto Inia sp. (Cetartiodactyla, Iniidae) in the Lower Reaches of the Tocantins and Guamá Rivers, Amazonia. In: SAMUELS, B.J. (Org.), Dolphins: Ecology, Behavior and Conservation Strategies. P 165-182. 2014.

SAVISHINSKY, J.S. Pet ideas: The domestication of animals, human behavior, and human emotions. In: KATCHER, A.H.; BECK, A. New perspectives on our lives with companion animals. University of Pennsylvania Press. Philadelphia, USA, p.31112. 1983.

SCHEFFER, V. Why should we care about whales? In: DAVES, N.; SMITH, A.M.; WHYTE, S.R.; WILLIAMS, V (Org.). Why Whales?. Whale and dolphin Conservation Society. Bath, Inglaterra. p.17-19. 1991.

SERPELL, J. In the company of animals: A study of human-animal relationships. Cambridge University Press. Cambridge, Inglaterra. 348pp. 1996.

SPINKA, M.; NEWBERRY, R. C.; BEKOFF, M. Mammalian play: Training for the unexpected. Quarterly Review of Biology. 76: 141-168. 2001.

TORRES, V. L. S. Envelhecimento e Pesca: redes sociais no estuário amazônico. 
CEJUP (Coleção Megam/3). Belém, Brasil, 239pp. 2004.

TUNNICLIFFE, S. D.; REISS, M. J. Students' understandings about animal skeletons. International Journal of Science Education. 21(11): 1187-1200. 1999.

United Nations Environment Programme (UNEP)/Convention on Migratory Species (CMS). Wildlife Watching and Tourism: A study on the benefits and risks of a fast growing tourism activity and its impacts on species. UNEP /CMS. Secretariat, Bonn, Germany. 68 pp. 2006.

VIERTLER, R. B. Métodos antropológicos como ferramenta para estudos em etnobiologia e etnoecologia. In: AMOROZO, M. C. M.; MING, L. C.; SILVA, S. P. (Org.) Métodos de coleta e análises de dados em etnobiologia, etnoecologia e disciplinas correlatas. CNPq, UNESP. São Paulo, Brasil. p11-29. 2002.

WILSON, E.O. Biophilia, The Human Bond With Other Species. Havard University Press, Cambridge. Massachusetts, EUA, 157pp. 1984.

YAMAMOTO, M. E.; CARVALHO, A. M. A. Brincar para quê? Uma abordagem etológica ao estudo da brincadeira. Estudos de Psicologia. 7(1): 161-164. 2002.

ZAPPES, C.A.; ALVES, C.P.S,; SILVA, C.V.; AZEVEDO, A.F, DI BENEDITTO, A.P.M.; ANDRIOLO, A. Accidents between artisanal fisheries and cetaceans on the Brazilian coast and Central Amazon: Proposals for integrated management. Ocean \& Coastal Management. 85: 46-57. 2013. 